\title{
Pengembangan Aplikasi Ujian Online Berbasis Website pada Mata Pelajaran Sistem Operasi Kelas X TKJ SMK Negeri 7 Jakarta
}

\author{
Winda Tristianti ${ }^{1}$, Yuliatri Sastrawijaya ${ }^{2}$, Prasetyo Wibowo Yunanto ${ }^{3}$ \\ ${ }^{1}$ Mahasiswa Prodi Pendidikan Teknik Informatika dan Komputer, Teknik Elektro, FT - UNJ \\ ${ }^{2,3}$ Dosen Prodi Pendidikan Teknik Informatika dan Komputer, Teknik Elektro, FT - UNJ \\ ${ }^{1}$ windaaatris@yahoo.com, ${ }^{2}$ yuliatri_s@yahoo.com, ${ }^{3}$ prast_elektro_unj@yahoo.com
}

\begin{abstract}
Abstrak
Sistem Operasi merupakan mata pelajaran produktif wajib dasar yang harus dikuasai siswa program keahlian TKJ di SMK Negeri 7 Jakarta. Feedback yang cepat diperlukan untuk membantu siswa dapat menguasai mata pelajaran tersebut. Mata pelajaran Sistem Operasi memanfaatkan teknologi komputer dan internet dalam proses pembelajarannya. Teknologi tersebut dapat memberikan peluang mata pelajaran Sistem Operasi untuk berinovasi dalam proses evaluasi pembelajaran salah satunya adalah menggunakan aplikasi ujian online berbasis website. Tujuan dari penelitian ini adalah untuk menghasilkan aplikasi ujian online berbasis website pada mata pelajaran Sistem Operasi kelas X jurusan TKJ di SMK Negeri 7 Jakarta yang efektif dan efisien agar dapat digunakan sebagai alternatif evaluasi hasil belajar siswa. Metode penelitian yang digunakan adalah metode penelitian dan pengembangan. Metode pengembangan sistemnya menggunakan metode waterfall. Sistem yang dikembangkan menggunakan bahasa pemrograman PHP dan pengolah basis data MySQL. Website ujian online dapat diakses dengan alamat web www.ujiansmkn7jkt.com. Berdasarkan hasil pengujian sistem terhadap kebutuhan fungsional, diketahui bahwa seluruh fungsi berjalan dengan baik dan sesuai harapan. Pengembangan website ujian online telah melalui tahap evaluasi ahli materi, evaluasi ahli media dan uji coba yang dilakukan oleh seluruh siswa kelas X TKJ SMK Negeri 7 Jakarta. Berdasarkan hasil uji coba, kualitas aplikasi ujian online berbasis website yang telah dikembangkan menurut persepsi 28 siswa adalah $78.4 \%$ dari yang diharapkan (100\%). Aplikasi ujian online berbasis website yang telah dikembangkan dapat dikatakan cukup baik sehingga dapat digunakan sebagai alternatif model penilaian hasil belajar mata pelajaran Sistem Operasi kelas X TKJ.
\end{abstract}

Kata Kunci: Aplikasi, Evaluasi, Sistem Operasi, Ujian Online, Website.

\section{PENDAHULUAN}

\subsection{Latar Belakang Masalah}

Information Communication Technology (ICT) atau Teknologi Informasi dan Komunikasi (TIK) semakin berkembang cepat di berbagai aspek kehidupan. Dunia pendidikan merupakan salah satu yang memanfaatkan perkembangan ICT. Perkembangan ICT tersebut membuat Sekolah Menengah Kejuruan di Indonesia salah satunya yaitu SMK Negeri 7 Jakarta yang terletak di Rawamangun Jakarta Timur, membuka program keahlian yang berhubungan dengan teknologi informasi seperti Multimedia dan Teknik Komputer dan Jaringan (TKJ).

Mata pelajaran Sistem Operasi merupakan salah satu mata pelajaran pada program keahlian Teknik Komputer dan Jaringan (TKJ) yang ada di SMK Negeri 7 Jakarta dan juga merupakan salah satu mata pelajaran produktif wajib dasar yang harus dikuasai oleh siswa program keahlian TKJ. Jika siswa tidak memahami mata pelajaan tersebut dengan baik siswa akan terasa sulit mengikuti pelajaran di tingkat yang lebih tinggi. Diperlukan feedback yang cepat untuk membantu peserta didik dapat menguasai mata pelajaran tersebut salah satunya adalah dengan test atau penilaian hasil belajar yang menunjang pemberian feedback yang cepat kepada peserta didik.

Sistem Operasi memanfaatkan teknologi komputer dan teknologi internet dalam proses pembelajarannya. Teknologi tersebut dapat memberikan peluang mata pelajaran Sistem Operasi untuk berinovasi dalam proses evaluasi pembelajaran. Dengan memanfaatkan perkembangan teknologi tersebut dapat menghasilkan suatu sistem yang bisa memberikan evaluasi secara cepat, tepat dan memudahkan dalam melakukan proses evaluasi. Sistem tersebut salah satunya adalah aplikasi ujian online berbasis website. Sistem aplikasi ujian online berbasis website menunjang pemberian feedback yang cepat kepada peserta didik seperti yang dibutuhkan mata pelajaran Sistem Operasi untuk membantu siswa mengetahui kemampuan dan kekurangannya agar dapat dengan cepat menguasai mata pelajaran tersebut.

1.2. Rumusan Masalah 
Bagaimana mengembangkan aplikasi ujian online berbasis website pada mata pelajaran Sistem Operasi kelas X TKJ SMK Negeri 7 Jakarta?

\subsection{Tujuan Penelitian}

Untuk menghasilkan ujian online berbasis website pada mata pelajaran Sistem Operasi kelas X jurusan TKJ di SMK Negeri 7 Jakarta yang efektif dan efisien agar dapat digunakan sebagai alternatif evaluasi hasil belajar siswa.

\section{KAJIAN TEORI}

\subsection{ICT (Information Communication Technology)}

ICT adalah sekumpulan perangkat dan sumber daya teknologi yang digunakan untuk berkomunikasi, penciptaan, penyebaran, penyimpanan dan pengelolaan informasi (Ariani, 2010: 171).

ICT juga dapat didefinisikan sebagai teknologi yang bertujuan membantu manusia untuk menjalani hidup dengan lebih mudah dan lebih baik dalam membuat, mengubah, menyimpan, mengkomunikasikan dan/atau menyebarkan informasi (Irwansyah dan Moniaga, 2014: v).

\subsection{Pembelajaran Berbasis ICT}

Pembelajaran berbasis ICT mencakup teknologi komputer dan internet. Komputer dapat digunakan sebagai alat mengajar utama untuk memberi penguatan belajar awal, merangsang dan memotivasi belajar, atau untuk berbagai jenis kemungkinan lainnya. (Mukhtar dan Iskandar, 2012: 330). Metode pembelajaran berbasis internet yang dapat dilakukan oleh guru dan peserta didik, diantaranya: diskusi, demonstrasi, problem solving, inkuiri, dan descoveri (Mukhtar dan Iskandar, 2012: 329).

Dengan memanfaatkan teknologi komputer dan internet diharapkan mampu mendukung kegiatan pembelajaran, membantu memudahkan proses pembelajaran bagi guru dan peserta didik, dan dapat membantu memecahkan masalah belajar karena pembelajaran berbasis komputer dan internet mendidik peserta didik untuk berpikir kritis, menambah wawasan dan pengetahuan, mendidik peserta didik untuk belajar otodidak, dan meningkatkan hasil belajar peserta didik sehingga mampu meningkatkan mutu pendidikan (Mukhtar dan Iskandar, 2012: 328).

\subsection{Mata Pelajaran Sistem Operasi}

Mata pelajaran Sistem Operasi adalah mata pelajaran produktif wajib dasar program keahlian Teknik Komputer dan Informatika termasuk Teknik Komputer dan Jaringan (TKJ) di sekolah kejuruan termasuk SMK Negeri 7 Jakarta. Mata pelajaran Sistem Operasi memanfaatkan teknologi komputer dan teknologi internet dalam proses pembelajarannya. Kurikulum yang digunakan adalah kurikulum 2013. Berdasarkan struktur kurikulum, mata pelajaran Sistem Operasi disampaikan di kelas $\mathrm{X}$ dengan alokasi waktu 3 jam pelajaran tiap pertemuan.

Sistem Operasi adalah perangkat lunak lapisan pertama yang diletakkan pada media penyimpan (hard disk) di komputer. Sistem Operasi akan melakukan layanan inti umum untuk perangkat lunak aplikasi. Sistem Operasi akan mengelola semua aktifitas komputer yang berkaitan dengan pengaksesan perangkat keras, pengelolaan proses seperti penjadwalan proses, dan pengelolaan aplikasi. Sistem Operasi mempunyai peranan yang sangat penting. Secanggih apapun perangkat keras komputer jika tidak didukung Sistem Operasi maka sistem komputer tersebut tidak akan ada manfaatnya (Munif, 2013: 1).

Untuk semester ganjil topik materi pembelajaran Sistem Operasi menekankan pada pemanfaatan Sistem Operasi closed source dalam hal ini adalah Sistem Operasi keluarga windows. Berdasarkan silabus mata pelajaran Sistem Operasi yang digunakan SMK Negeri 7 Jakarta, Kompetensi Dasar (KD) ranah kognitif yang dimiliki yaitu memahami perkembangan sistem operasi closed source, memahami struktur sistem operasi closed source, memahami proses booting pada sistem operasi closed source, memahami instalasi sistem operasi closed source, memahami administrasi sistem operasi closed source dan memahami prosedur pencarian kesalahan pada sistem operasi closed source.

\subsection{Evaluasi Pembelajaran}

Evaluasi pembelajaran adalah proses pengumpulan keterangan-keterangan secara sistematis tentang pengaruh usaha guru untuk dianalisis agar dapat diketahui apakah dan hingga manakah tujuan pelajaran telah dicapai (Nasution, 1982: 73).

Menurut Sunarti dan Rahmawati (2014: 8), evaluasi pembelajaran atau penilaian dapat digunakan untuk:

1. Umpan balik/feedback bagi siswa dalam mengetahui kemampuan dan kekurangannya, sehingga menimbulkan motivasi untuk memperbaiki hasil belajarnya.

2. Memantau kemajuan dan mendiagnosis kemampuan belajar siswa sehingga memungkinkan dilakukannya pengayaan dan remidiasi untuk memenuhi kebutuhan siswa sesuai dengan kemajuan dan kemampuannya.

3. Memberikan masukan bagi guru untuk memperbaiki program pembelajarannya di kelas.

4. Memungkinkan siswa mencapai kompetensi yang telah ditentukan, walaupun dengan kecepatan belajar yang berbeda-beda.

\subsection{Tes Bentuk Pilihan Ganda}


Mata pelajaran Sistem Operasi merupakan pelajaran ranah kognitif dengan salah satu bentuk penilaiannya adalah bentuk pilihan ganda atau mutiple choice. Menurut Sunarti dan Rahmawati (2014: 36-37), kaidah penulisan tes obyektif pilihan ganda harus memperhatikan aspek materi, konstruksi dan bahasa. Dari aspek materi sebagai berikut:

1. Butir soal sesuai indikator.

2. Batasan pertanyaan dan jawaban yang diharapkan jelas.

3. Isi materi sesuai dengan tujuan pengukuran.

4. Materi yang ditanyakan sesuai dengan jenjang, jenis sekolah dan tingkat kelas.

5. Pilihan benar-benar berfungsi. Jika pilihan merupakan hasil perhitungan, maka pengecoh berupa pilihan yang salah rumus/hitung.

Dari aspek konstruksi sebagai berikut:

1. Pokok soal dirumuskan dengan jelas.

2. Rumusan soal dan pilihan dirumuskan dengan tegas.

3. Pokok soal tidak memberi petunjuk/mengarah pada pilihan jawaban yang benar.

4. Pokok soal tidak mengandung pernyataan negatif.

5. Pilihan jawaban homogen.

6. Hindari alternatif jawaban: "seluruh jawaban diatasbenar" atau "tidak ada satu jawaban yang benar" dan sejenisnya.

7. Panjang alternatif jawaban relatif sama jangan ada yang sangat panjang dan sangat pendek.

8. Antar butir tidak bergantung satu sama lain.

9. Wacana, gambar, atau tabel benar-benar berfungsi.

Dari aspek bahasa sebagai berikut:

1. Rumusan kalimat komunikatif

2. Menggunakan bahasa indonesia yang baik dan benar

3. Rumusan kalimat tidak menimbulkan penafsiran ganda atau salah pengertian.

4. Menggunakan bahasa/kata umum (bukan lokal).

5. Rumusan soal tidak mengandung kata-kata yang menyinggung perasaan siswa.

\subsection{Penyusunan Ujian}

Langkah-langkah penyusunan ujian harus dilakukan agar soal yang disiapkan setiap guru menghasilkan bahan ujian yang sahih dan andal sehingga dapat digunakan sebagai ukuran untuk mengetahui apakah proses pembelajaran telah mencapai hasil dari tujuan yang ditentukan atau tidak. Berikut ini merupakan langkah-langkah pelaksanaan penyusunan butir soal, yaitu:

1. Menentukan tujuan penilaian/tes

2. Menentukan jumlah butir soal yang akan diujikan

3. Menentukan penyebaran butir soal

4. Membuat kisi-kisi

5. Menulis Soal Tes

6. Telaah Butir Soal
7. Uji Coba Instrumen Penilaian

8. Analisis Butir Soal

\subsection{Aplikasi Berbasis Website}

Aplikasi adalah program yang memiliki aktivitas pemrosesan perintah yang diperlukan untuk melaksanakan permintaan pengguna dengan tujuan tertentu (Supriyanto, 2005: 117).

Halaman web atau Website merupakan sebuah halaman berisi informasi yang dapat dilihat jika komputer ada terkoneksi dengan internet. Dengan adanya website, semua orang di dunia bisa mendapatkan dan mengelola informasi dengan berbagai sumber yang tersedia di internet (Wahana Komputer, 2010: 1).

\subsection{Aplikasi Ujian Online Berbasis Website}

Aplikasi ujian online berbasis website adalah aplikasi yang dapat digambarkan sebagai sebuah sistem terintegrasi, sistem manusia-mesin yang memanfaatkan perangkat keras dan perangkat lunak komputer, jaringan internet, prosedur manual dan basis data untuk mengadakan ujian secara lebih cepat dan efektif (Tulangow, 2011: 37).

Menurut Nursalam dan Efendi (2011: 139) terdapat beberapa kelebihan lain dari ujian online, yaitu:

1. Peserta dapat menerima umpan balik cepat dari tes yang telah dikerjakan.

2. Memudahkan peserta mengerjakan ujian dari jarak jauh.

3. Penilaian sangat efisien menghemat waktu staf.

\subsection{Arsitektur Aplikasi Ujian Online Berbasis} Website

Aplikasi ujian online harus dapat berfungsi sebagai basis data yang baik. Aplikasi ujian online harus mampu menampung data soal ujian, peserta ujian, jawaban peserta ujian, waktu ujian, serta data lain yang perlu disimpan dan jika diperlukan sewaktu-waktu dapat ditampilkan atau dicetak. Karena itu arsitektur sistem aplikasi ujian online biasanya berupa web database client-server. Sebagai web database client server, pengembangan website aplikasi ujian online dapat menggunakan banyak program dan bahasa pemrograman. Program XAMPP yang mengintegrasikan Apache web server dan MySql yang open source sangat mendukung pengembangan aplikasi ujian di komputer stand alone atau di komputer yang tidak terhubung ke jaringan. Bahasa pemrograman yang umum dan banyak sekali digunakan oleh para pengembang website adalah bahasa PHP (Hadi, 2013: 20).

\subsection{Aspek Pengembangan Website}

Menurut Suyanto dan herman (2007: 61-69), terdapat beberapa aspek yang perlu diperhatikan dalam pengembangan website, yaitu: (1) Usability, (2) Sistem navigasi (struktur), (3) Graphic Design 
(Desain visual), (4) Contents, (5) Compatibility, (6) Loading Time, (7) Functionality, (8) Accesibility, dan (9) Interactivity.

Menurut Labulan dan Efendi (2012: ) media ujian online harus memperhatikan aspek tampilan dan aspek pemrograman. Pentingnya aspek tampilan ini didasarkan pada bagaimana agar teks soal, petunjuk serta semua informasi yang terkandung dalam perangkat tes mudah terbaca bagi pengguna. Sedangkan aspek pemrograman didasarkan pada bagaimana program berjalan apakah masih terdapat kesalahan atau tidak.

\subsection{Metode Pengembangan Waterfall}

Metode waterfall merupakan salah satu metode yang digunakan dalam pengembangan sistem aplikasi. Metode pengembangan waterfall memiliki ciri pengerjaan setiap tahap harus diselesaikan terlebih dahulu sebelum melanjutkan ke tahap berikutnya. Tahapan-tahapan dari metode waterfall yaitu: (1) Analisis dan Definisi Persyaratan, (2) Perancangan, (3) Implementasi, (4) Integrasi dan Pengujian, dan (5) Operasi dan Pemeliharaan (Sommerville, 2003: 42-44).

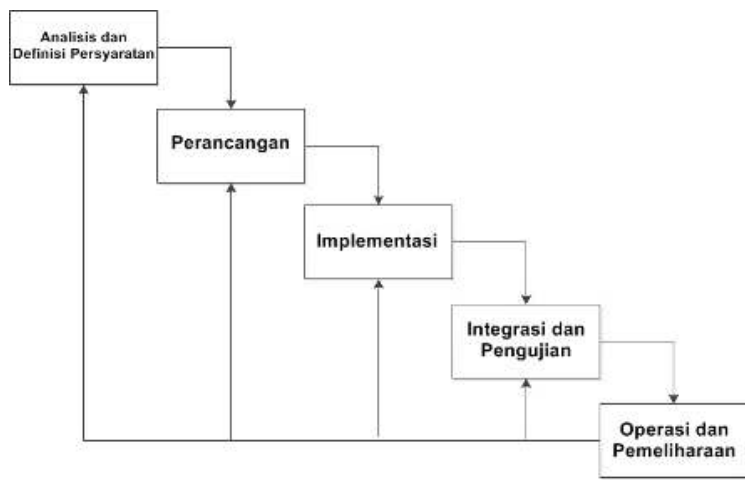

\section{Gambar 2.1. Metode Waterfall}

\section{METODOLOGI PENELITIAN}

\subsection{Latar Penelitian}

Penelitian dilakukan di SMK Negeri 7 Jakarta yang terletak di Jalan Tenggiri No.1 Rawamangun Jakarta Timur.

\subsection{Metode Penelitian}

Metode yang digunakan dalam penelitian ini adalah metode penelitian dan pengembangan (Research and development). Model penelitian ini sering disebut dengan R\&D. R\&D adalah suatu proses atau langkah-langkah untuk mengembangkan suatu produk baru atau menyempurnakan produk yang telah ada, yang dapat dipertanggung jawabkan. Produk tersebut tidak selalu berbentuk benda atau perangkat keras (hardware), seperti buku, modul, alat bantu pembelajaran dikelas atau laboratorium, tetapi bisa juga perangkat lunak (software) (Sugiyono, 2013: 407).

\subsection{Prosedur Penelitian}

Sugiyono (2013: 409) memaparkan sepuluh langkah pelaksanaan strategi penelitian dan pengembangan, yaitu: (1) Potensi dan masalah, (2) Pengumpulan Data, (3) Desain Produk, (4) Validasi Desain, (5) Revisi Desain, (6) Uji Coba Produk, (7) Revisi Desain, (8) Uji Coba Pemakaian, (9) Revisi Produk, (10) Produk Massal.

Sedangkan Sukmadinata dan Syaodih (2006: 189) mengembangkan metode penelitian dan pengembangan dalam 3 langkah, yaitu: (1) Studi Pendahuluan yang terdiri atas kajian pustaka dan studi lapangan, (2) Pengembangan yang meliputi penyusunan draf awal, uji coba terbatas dan uji coba luas, (3) Pengujian yang dilaksanakan dalam bentuk eksperimen.

Dalam mengembangkan media pembelajaran, Mardika (2008: 13) mengadaptasi model penelitian pengembangan Borg \& Gall, model pengembangan desain pembelajaran Dick \& Carey, dan pengembangan produk model Luther. Model penelitian Mardika meliputi enam tahap, yaitu (1) Analisis Kebutuhan, (2) Desain Pembelajaran, (3) Produksi Multimedia, (4) Validasi Ahli, (5) Revisi, (6) Uji Coba Produk.

Ketiga model metode penelitian dan pengembangan tersebut diadaptasi sehingga menghasilkan sebuah model yang dijadikan sebagai landasan dalam penelitian ini. Berikut ini merupakan skema tahapan metode penelitian dan pengembangan yang digunakan dalam pengembangan aplikasi ujian online berbasis website.

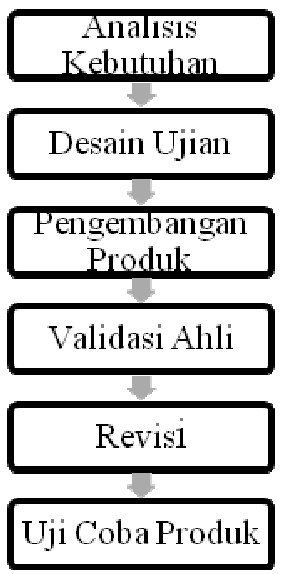

Gambar 3.1. Model R\&D Diadaptasi dari Sugiyono, Sukmadinata, dan Mardika

\section{A. Analisis Kebutuhan}

Tahap ini merupakan analisis pendahuluan untuk mengumpulkan informasi mengenai mata pelajaran Sistem Operasi dan perlunya pengembangan website ujian online pada mata pelajaran Sistem Operasi kelas X TKJ di SMKN 7 Jakarta. Informasi tentang kebutuhan pengembangan website ujian online dilakukan dengan survey ke SMK Negeri 7 Jakarta, melakukan wawancara 
dengan guru mata pelajaran Sistem Operasi dan menyebar angket ke seluruh siswa kelas X TKJ.

\section{B. Desain Ujian}

Setelah mengetahui kebutuhan melalui analisis maka tahap menyusun ujian Sistem Operasi dilakukan. Tahap ini meliputi penentuan golongan ujian, penentuan jumlah butir soal, penentuan penyebaran butir soal, pembuatan kisi-kisi dan menulis butir-butir soal yang akan dimasukkan dalam aplikasi ujian online yang akan dikembangkan.

\section{Pengembangan Produk}

Dalam tahap ini dilakukan proses pembuatan produk yaitu aplikasi ujian online berbasis website. Website ujian online dikembangkan menggunakan metode waterfall. Pada proses pengembangan produk dilakukan tahap uji fungsionalitas untuk menguji apakah website sudah memenuhi seluruh fungsi yang diinginkan atau belum dan apakah terdapat kesalahan atau tidak.

\section{Validasi Ahli}

Setelah produk awal telah dibuat, dilakukan penilaian dari dari para ahli, ahli materi dan ahli media. Penilaian ahli merupakan proses untuk memvalidasi kelayakan produk yang dikembangkan. Ahli materi untuk mengevaluasi butir-butir soal ujian Sistem Operasi yang telah disusun dan ahli media untuk mengevaluasi website ujian online. Proses penelitian dilakukan dengan menggunakan instrumen evaluasi ahli dan dianalisis secara deskriptif.

\section{E. Revisi}

Setelah mendapatkan saran dari para penilai mengenai materi dan media, dilakukan perbaikan untuk menyempurnakan produk. Setelah produk diperbaiki dilakukan uji coba produk.

\section{F. Uji Coba produk}

Uji coba produk merupakan tahap terakhir dalam prosedur penelitian. Pada tahap ini dilakukan uji coba pelaksanaan ujian mata pelajaran Sistem Operasi menggunakan website ujian online dengan subjeknya adalah seluruh siswa kelas X TKJ SMKN 7 Jakarta. Penelitian dilakukan dengan menggunakan instrumen uji coba berupa angket untuk mengetahui seberapa baik ujian online yang dikembangkan sehingga dapat digunakan menjadi alternatif model evaluasi pembelajaran. Angket menggunakan skala pengukuran rating scale. Rentang angka yang digunakan yaitu 1-4. Perolehan skor yang didapatkan dari angket kemudian dihitung persentasenya. Angka persentase yang dihasilkan dapat diinterpretasikan dalam beberapa kategori. Penilaian seberapa baik website ujian online secara kontinum dapat dibuat kategori sebagai berikut: (Sugiyono, 2013: 144).

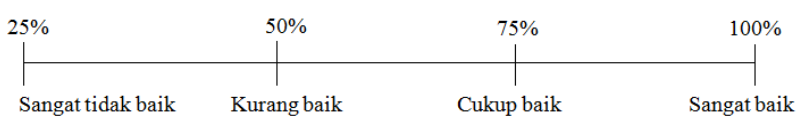

\section{Gambar 3.2. Garis Kontinum}

Selain itu pada tahap ini juga dilakukan analisis terhadap kinerja sistem secara keseluruhan selama uji coba pelaksanaan ujian.

\subsection{Rancangan Sistem}

A. Diagram Sistem Ujian Online

Berikut ini ditampilkan diagram alur proses yang terjadi didalam operasional sistem berdasarkan fungsi kebutuhan masing-masing user.

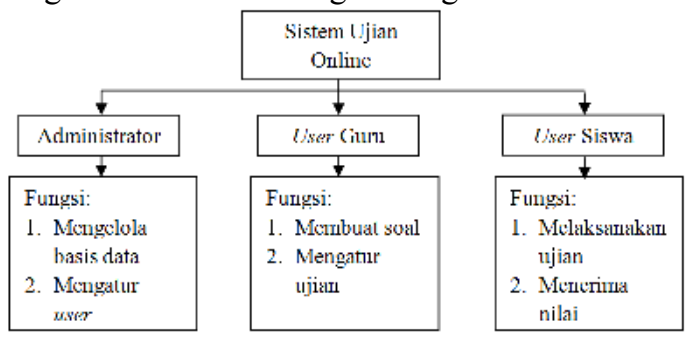

\section{Gambar 3.3. Diagram Sistem Ujian Online}

\section{B. Diagram Konteks}

Diagram konteks menunjukkan garis besar dari alur proses dalam sistem. Berdasarkan definisi fungsi entitas user guru, user siswa, dan administrator dibuat konteks diagram sebagai berikut:

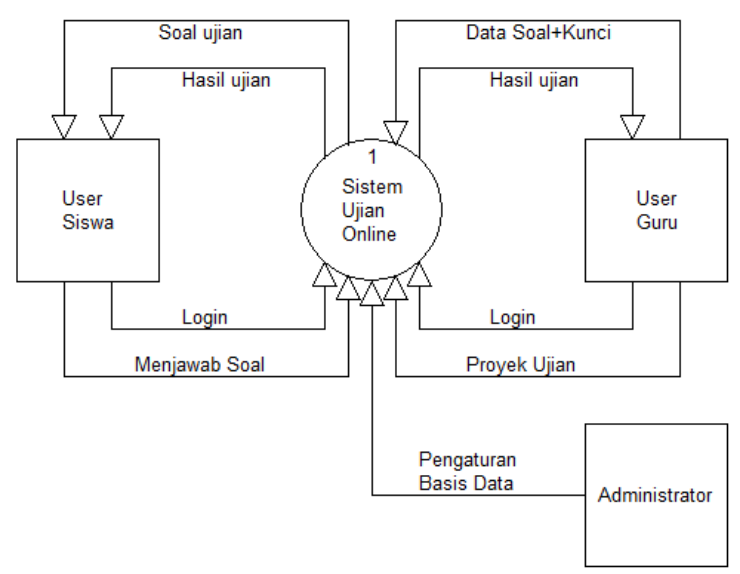

\section{Gambar 3.4. Diagram Konteks}

\section{Entitiy Relationship Diagram}

ERD merupakan salah satu model yang digunakan untuk mendesain database dengan tujuan menggambarkan data yang berelasi pada sebuah database. Berikut ini merupakan ERD ujian online. 


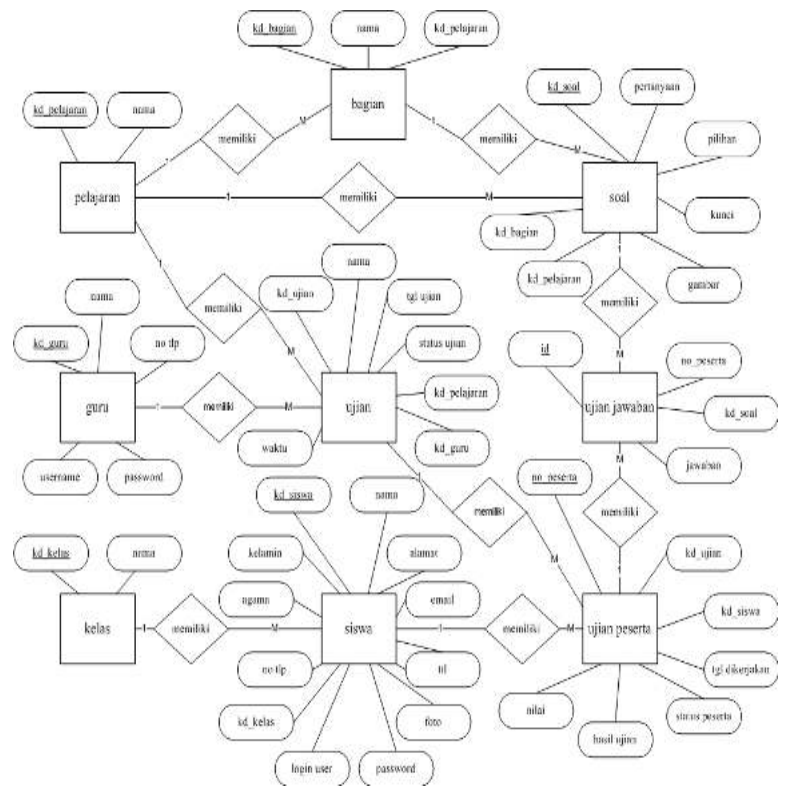

Gambar 3.5. ERD Ujian Online

\section{Relasi Tabe}

Relationship tables atau relasi tabel merupakan hubungan yang terjadi pada suatu tabel dengan tabel lainnya. Berfungsi mengatur operasi suatu database. Berikut ini merupakan gambar relasi tabel dari aplikasi ujian online.

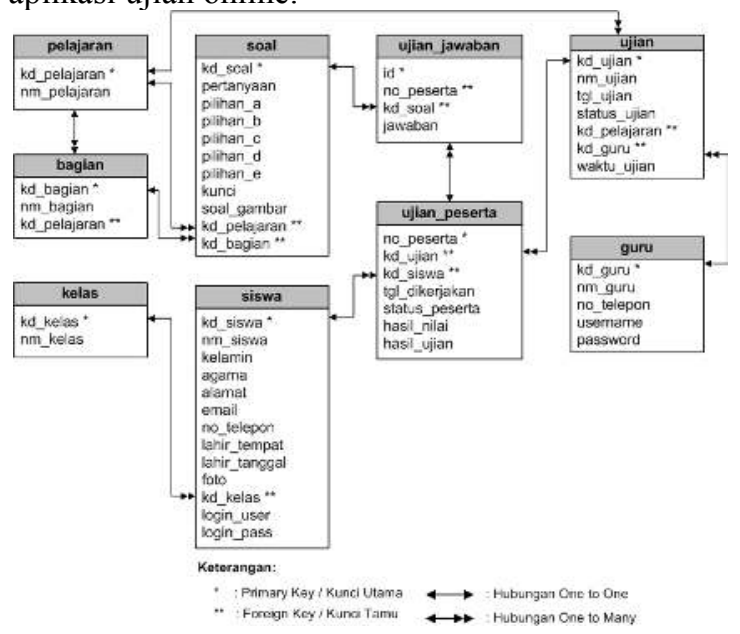

Gambar 3.6. Relasi Tabel Ujian Online

\section{HASIL DAN PEMBAHASAN}

4.1. Hasil

A. Hasil Tampilan

Berikut ini merupakan gambar halaman utama website ujian online.

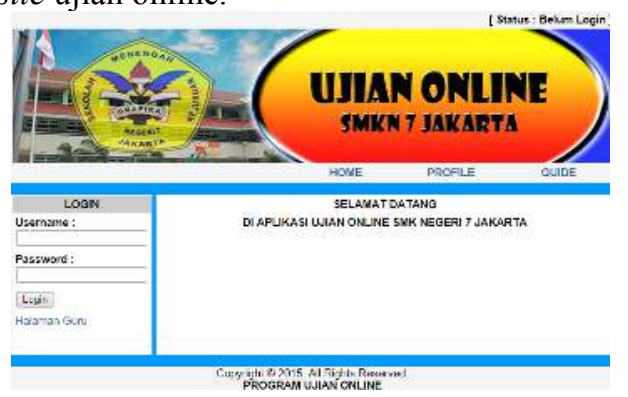

Gambar 4.1. Tampilan Halaman Utama
Halaman utama merupakan tampilan awal dimana website pertama kali dibuka. Terdapat form login untuk peserta, link untuk menuju halaman guru, menu profile untuk mengetahui info tentang aplikasi ujian online, dan menu guide untuk melihat panduan menggunakan aplikasi ujian online.

Untuk mengakses halaman peserta, peserta atau siswa harus melakukan login terlebih dahulu dengan memasukkan username dan password yang didapatkan dari guru. Berikut ini merupakan halaman peserta.

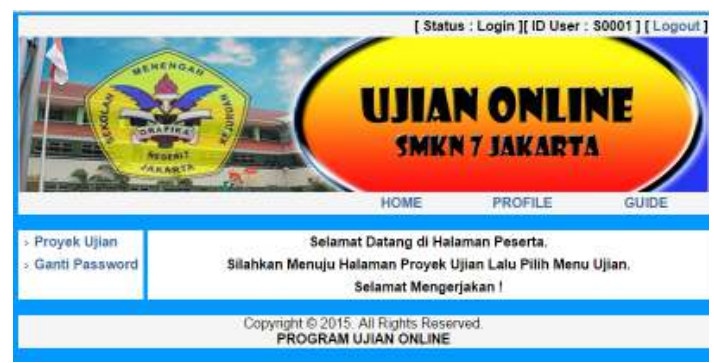

Gambar 4.2. Tampilan Halaman Peserta

Didalam halaman peserta, terdapat menu proyek ujian dan ganti password. Proyek ujian untuk menuju halaman daftar ujian yang akan dikerjakan dan menu ganti password untuk menuju halaman untuk siswa jika ingin mengganti password yang sebelumnya guru berikan.

Setelah klik mulai pada daftar ujian yang ada di halaman proyek ujian, maka akan masuk ke halaman pelaksanaan ujian. Soal ujian ditampilkan 1 soal tiap halaman. Untuk menjawab soal, peserta memilih jawaban lalu menekan tombol simpan jawaban. Setelah itu klik tombol nomor soal untuk menuju soal berikutnya. Terdapat waktu untuk mengetahui sisa waktu pelaksanaan ujian. Setelah waktu habis, secara otomatis keluar dari halaman peserta dan berarti pelaksanaan ujian telah selesai. Berikut ini merupakan gambar halaman pelaksanaan ujian.

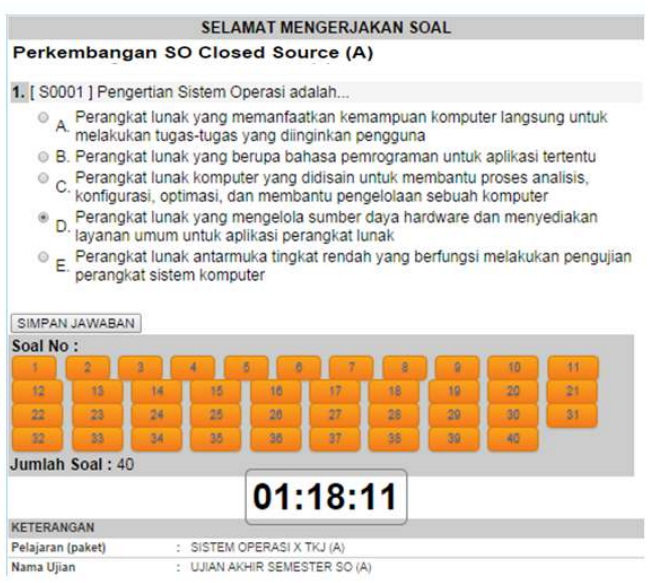

Gambar 4.3. Tampilan Halaman Ujian

Untuk melihat hasil, peserta login kembali setelah menunggu konfirmasi dari guru. Setelah login, menuju kembali ke halaman proyek ujian lalu klik tombol hasil pada menu. Setelah klik tombol hasil maka akan masuk ke halaman hasil ujian. Halaman ini menampilkan hasil ujian berisi nilai, 
jawaban yang dijawab peserta, jawaban yang dijawab benar dan yang dijawab salah dan kunci jawaban soal. Berikut ini merupakan gambar halaman hasil ujian.

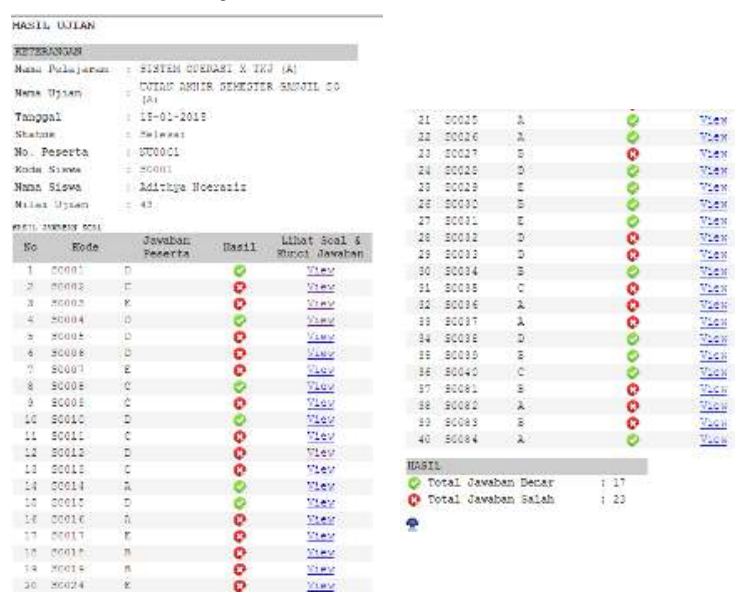

Gambar 4.4. Tampilan Halaman Hasil Ujian

Untuk menuju halaman guru, pada halaman utama klik link Halaman Guru di bawah form login peserta. Setelah itu melakukan proses login terlebih dahulu dengan mengisi username dan password yang sudah diinput oleh administrator dalam database. Setelah melakukan proses login akan langsung masuk ke halaman home. Terdapat menu utama yaitu: (1) Data Guru; untuk melihat data guru yang dapat mengakses halaman guru, (2) Data kelas; untuk pengaturan data kelas, (3) Data siswa; untuk pengaturan data siswa, (4) Data pelajaran; untuk pengaturan data pelajaran yang akan diuji, (5) Data materi; untuk pengaturan kompetensi dasar atau materi pelajaran, (6) Data soal ujian; untuk pengaturan butir-butir soal yang akan diuji, (7) Data proyek ujian; untuk pengaturan proyek ujian yang akan diujikan, (8) Data penilaian ujian; merupakan halaman untuk memproses hasil ujian peserta, berisi nilai dan hasil pengerjaan peserta, (9) Data laporan hasil ujian; berisi daftar hasil ujian, dan logout; untuk keluar dari halaman guru. Berikut ini merupakan gambar halaman guru.

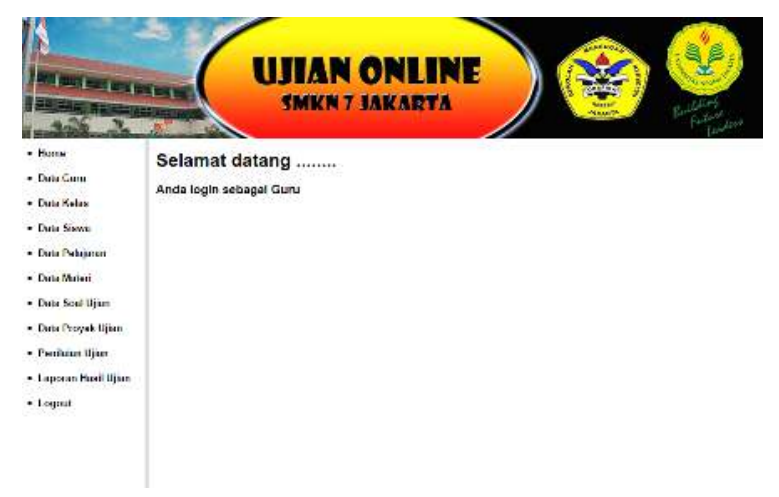

\section{Gambar 4.5. Tampilan Halaman Guru}

Melalui halaman penilaian ujian guru dapat memantau hasil pengerjaan siswa selama pelaksanaan ujian berlangsung. Melalui halaman ini pula hasil ujian dapat ditampilkan ke halaman peserta setelah pelaksanaan ujian selesai. Hasil ujian dapat dilihat oleh peserta setelah guru menekan tombol simpan hasil. Berikut ini merupakan halaman penilaian ujian.

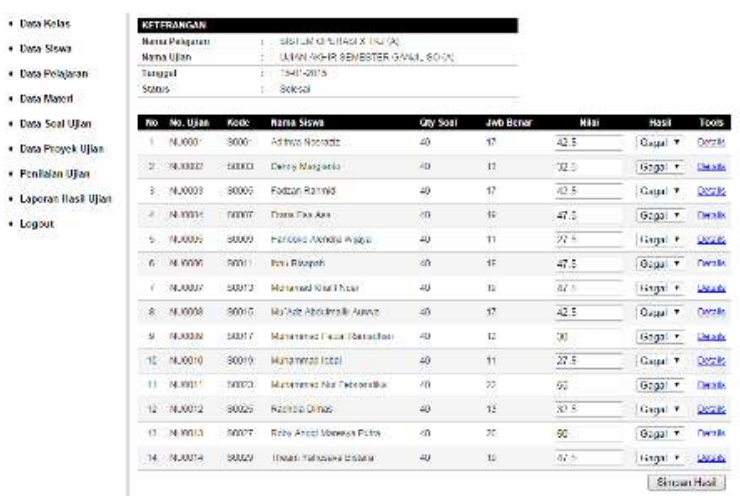

Gambar 4.6. Tampilan Halaman Penilaian Ujian B. Hasil Uji Fungsional

Pada tahap pengembangan produk perlu dilakukan pengujian sistem. Pengujian yang dilakukan adalah pengujian sistem secara fungsional (functional testing). Dalam tahap pengujian fungsional dihasilkan bahwa seluruh fungsi berjalan dengan baik dan sesuai harapan.

\section{Hasil Evaluasi Ahli Materi}

Setelah tahap menyusun ujian Sistem operasi seperti penentuan golongan ujian, penentuan jumlah butir soal, penentuan penyebaran butir soal, pembuatan kisi-kisi dan menulis butir-butir soal, maka dilakukan evaluasi dari ahli materi untuk mengevaluasi butir-butir soal ujian sistem operasi yang telah disusun. Evaluasi dilakukan menggunakan instrumen evaluasi ahli materi dengan aspek yang dinilai yaitu aspek materi, aspek konstruksi dan aspek bahasa. Berdasarkan hasil evaluasi dari ahli materi, materi yang disajikan sudah sesuai dengan aspek-aspek yang harus diperhatikan.

\section{Hasil Evaluasi Ahli Media}

Setelah tahap uji fungsi dan tidak terdapat kesalahan maka dilanjutkan dengan evaluasi ahli media untuk mengevaluasi produk media yang telah dibuat yaitu aplikasi ujian online berbasis website. Terdapat 7 aspek yang dapat dinilai dalam pengembangan website ujian online yaitu desain visual, loading time, interactivity, kompatibilitas, fungsionality, usability dan content. Namun dalam hal ini aspek content tidak perlu dinilai oleh ahli media karena aspek content merupakan soal yang disajikan dalam website ujian online dan soal ujian termasuk ke dalam penilaian ahli materi.

Evaluasi dilakukan menggunakan instrumen evaluasi ahli media. Berdasarkan hasil evaluasi dari ahli media, media yang dihasilkan sudah sesuai 
dengan aspek-aspek yang harus diperhatikan dan dapat dilanjutkan ke tahap uji coba.

\section{E. Hasil Interpretasi Siswa}

Untuk mengetahui seberapa baik aplikasi ujian online berbasis website untuk mata pelajaran sistem operasi kelas X di SMK Negeri 7 Jakarta, digunakan instrumen berupa angket dengan bantuan rating scale dengan rentang skor 1-4 dan diberikan kepada seluruh siswa TKJ berjumlah 28 siswa sebagai subjek yang menilai produk. Berikut ini merupakan hasil interpretasi siswa terhadap aplikasi ujian online.

Tabel 4.1. Skor Hasil Interpretasi Siswa

\begin{tabular}{|c|l|c|}
\hline No & \multicolumn{1}{|c|}{ Pernyataan } & Skor \\
\hline 1 & $\begin{array}{l}\text { Soal ujian akhir semester ganjil } \\
\text { sistem operasi yang disajikan ujian } \\
\text { online sesuai dengan Kompetensi } \\
\text { Inti (KI), Kompetensi Dasar (KD), } \\
\text { dan Indikator materi yang telah } \\
\text { dipelajari. }\end{array}$ & 90 \\
\hline 2 & $\begin{array}{l}\text { Website ujian online mudah } \\
\text { digunakan. }\end{array}$ & 88 \\
\hline 3 & $\begin{array}{l}\text { Tidak membutuhkan wkatu yang } \\
\text { lama untuk mengetahui hasil ujian. }\end{array}$ & 87 \\
\hline 4 & $\begin{array}{l}\text { Website ujian online memudahkan } \\
\text { untuk mengetahui hasil koreksi dan } \\
\text { kunci jawaban soal. }\end{array}$ & 88 \\
\hline \multicolumn{2}{|l|}{$\begin{array}{l}\text { Ujian online seperti ini perlu } \\
\text { diterapkan untuk mata pelajaran } \\
\text { lain }\end{array}$} & 86 \\
\hline \multicolumn{2}{|c|}{ Total skor hasil pengumpulan data } \\
\hline
\end{tabular}

Dari hasil uji coba dapat dilihat total skor pengumpulan data adalah 439 dan skor ideal adalah 560 (skor tertinggi $\mathrm{x}$ jumlah responden $\mathrm{x}$ jumlah butir). Dengan demikian kualitas aplikasi ujian online berbasis website yang telah dikembangkan menurut persepsi 28 siswa kelas X TKJ adalah (439 : 560) x $100 \%=78.4 \%$ dari yang diharapkan $(100 \%)$. Berdasarkan kategori interpretasi yang telah ditentukan, 78.4\% termasuk ke dalam kategori interval "cukup baik dan sangat baik". Tetapi lebih mendekati cukup baik.

\subsection{Pembahasan}

Pengembangan aplikasi ujian online berbasis website dibuat menggunakan banyak program pendukung dan bahasa pemrograman. Pembuatan database menggunakan MySQL sebagai database server dan menggunakan aplikasi PHPMyAdmin. Mendesain web menggunakan Adobe Dreamweaver versi CS6 dan bahasa pemrograman yang digunakan yaitu PHP. Program XAMPP digunakan sebagai web server sementara. Agar aplikasi ujian online dapat diakses oleh seluruh user (guru dan siswa), website dipindah ke hosting online dengan nama domain www.ujiansmkn7jkt.com. Website yang dikembangkan terbagi menjadi halaman untuk peserta tes (siswa) dan halaman guru. Halaman untuk siswa mencakup halaman proyek ujian, halaman pelaksanaan ujian yang berisi butir-butir soal yang harus dikerjaan, dan halaman informasi hasil ujian. Sedangkan halaman guru yang hanya bisa diakses oleh guru yang telah terdaftar dalam database, berisi seperti halaman data pelajaran, data siswa, data kelas, data proyek ujian dan penilaian hasil ujian.

Ujian yang disajikan dalam website adalah ujian akhir semester ganjil sistem operasi. Terdapat dua paket soal masing-masing berjumlah 40 butir dengan 9 bagian materi pelajaran yaitu perkembangan SO closed source, arsitektur SO, penjadwalan proses, manajemen $\mathrm{I} / \mathrm{O}$, proses booting SO closed source, partisi, instalasi SO closed source, dan administrasi SO.

Pada proses pengembangan website, dilakukan pengujian sistem secara fungsional (functional testing). Aplikasi diuji untuk persyaratan fungsional dan dilakukan dalam bentuk tertulis. Dalam tahap pengujian fungsional dihasilkan bahwa seluruh fungsi berjalan dengan baik dan sesuai harapan.

Dalam pengembangan aplikasi ujian online berbasis website perlu diperhatikan beberapa hal yaitu soal mata pelajaran yang disajikan dan media yang dikembangkan. Butir-butir soal ujian akhir semester ganjil mata pelajaran sistem operasi yang disajikan telah melalui tahap evaluasi ahli materi dan media website ujian online telah melalui tahap evaluasi ahli media. Setelah melalui tahap evaluasi ahli dihasilkan bahwa materi yang disajikan dan media yang dihasilkan dapat dikatakan layak karena sudah sesuai dengan aspek-aspek yang harus diperhatikan.

Setelah pengembangan aplikasi ujian online berbasis website untuk mata pelajaran sistem operasi kelas X TKJ SMK Negeri 7 Jakarta telah selesai, dilakukan uji coba produk sebagai tahap akhir untuk menentukan seberapa baik website ujian online. Uji coba ujian mata pelajaran Sistem Operasi dengan menggunakan aplikasi ujian online berbasis website dilakukan di lab TKJ dan teknis pelaksanaan ujian yaitu tempat duduk peserta sudah ditentukan terlebih dahulu secara urut berdasarkan nomor urut siswa. Menurut persepsi seluruh siswa TKJ kelas X SMK Negeri 7 Jakarta berjumlah 28 siswa, kualitas aplikasi ujian online yang dikembangkan yaitu $78.4 \%$ dari yang diharapkan (100\%). Berdasarkan kategori interpretasi yang telah ditentukan, 78.4\% termasuk ke dalam kategori interval "cukup baik dan sangat baik" tetapi lebih mendekati cukup baik. Sehingga dapat dikatakan bahwa aplikasi ujian online berbasis website pada mata pelajaran sistem operasi kelas X TKJ di SMK Negeri 7 Jakarta merupakan aplikasi berbasis website yang cukup baik dan dapat digunakan sebagai alternatif evaluasi hasil belajar siswa.

Namun dalam tahap uji coba kinerja sistem ujian online, ditemukan beberapa kendala yaitu 
kesulitan mengakses website secara lancar yang disebabkan oleh buruknya kualitas server hosting yang digunakan sehingga peserta sering kehilangan koneksi internet saat pelaksanaan ujian dan harus sering me-refresh halaman. Kendala lainnya yaitu dalam menjawab soal, setelah pilih jawaban peserta harus menyimpan jawaban terlebih dahulu. Hal itu memungkinkan peserta lupa menyimpan jawaban. Selain itu, setelah menjawab soal, tidak ada penanda bahwa soal tersebut telah terjawab. Hal itu membuat siswa kesulitan jika ingin melewati soal yang dia anggap sulit.

\section{KESIMPULAN DAN SARAN}

\subsection{Kesimpulan}

Berdasarkan hasil dan pembahasan yang telah dijelaskan sebelumnya, dapat diambil beberapa kesimpulan sebagai berikut:

1. Aplikasi ujian online berbasis website dikembangkan menggunakan MySQL dan PHPMyAdmin dalam pembuatan database, dengan bahasa pemrograman yang digunakan yaitu PHP serta didukung adobe dreamweaver CS6 untuk mendesain web secara visual.

2. Website ujian online menyajikan ujian semester ganjil mata pelajaran sistem operasi kelas X TKJ di SMK Negeri 7 Jakarta.

3. Berdasarkan hasil pengujian fungsional website, dihasilkan bahwa seluruh fungsi berjalan dengan baik dan sesuai harapan. Berdasarkan evaluasi ahli materi, butir-butir soal yang disajikan sudah sesuai dengan aspek yang perlu diperhatikan dalam penyusunan soal dan berdasarkan ahli media, website ujian online yang dikembangkan sudah sesuai dengan aspek yang perlu diperhatikan dalam pengembangan website ujian online.

4. Berdasarkan interpretasi 28 siswa kelas $\mathrm{X}$ TKJ SMK Negeri 7 Jakarta, dapat dikatakan bahwa aplikasi ujian online berbasis website yang dikembangkan merupakan website ujian online yang cukup baik sehingga dapat digunakan sebagai alternatif evaluasi hasil belajar siswa.

5. Berdasarkan analisis terhadap kinerja sistem dalam tahap uji coba, server hosting yang digunakan website ujian online menjadi kendala sehingga menyebabkan aplikasi ujian online tidak dapat berjalan lancar sesuai harapan.

\subsection{Saran}

Penulis mengerti bahwa media ini belumlah sempurna dan masih banyak kekurangan. Dengan berbagai keterbatasan yang dialami oleh penulis dalam mengembangkan sistem, maka penulis memberikan beberapa saran yang kiranya bisa menjadi bahan pertimbangan untuk pengembangan sistem dimasa yang akan datang, diantaranya sebagai berikut:

1. Harus menggunakan server hosting dan server lokal yang memiliki kualitas sangat baik sehingga pelaksanaan ujian online dapat terlaksana.

2. Dalam menjawab soal peserta tidak harus menekan tombol simpan jawaban. Setelah peserta memilih jawaban, jawaban tersimpan secara otomatis.

3. Perlu penanda bahwa soal sudah terjawab. Misalnya perubahan warna pada tiap tombol nomor soal jika soal nomor tersebut sudah terjawab.

4. Pengembangan terhadap algoritma yang dituangkan masih sangat sederhana, sehingga masih perlu lagi dikembangkan lebih lanjut sehingga sistem ini menjadi lebih baik dan dinamis.

5. Bentuk penilaian pada aplikasi ini hanya terbatas pada bentuk pilihan ganda. Diharapkan dapat dikembangkan bentuk penilaian essay didalamnya.

6. Peningkatan desain antar muka yang lebih menarik.

\section{DAFTAR PUSTAKA}

Abdul, Munif. 2013. Sistem Operasi Teknologi Informasi dan Komunikasi. Jakarta: Kementerian Pendidikan dan Kebudayaan Republik Indonesia.

Ariani, Niken. 2010. Pembelajaran Multimedia di Sekolah. Jakarta: Prestasi Pustakarya.

Hadi, Samsul. 2013. Pengembangan Computerized Adaptive Test Berbasis Web. Yogyakarta: Aswaja.

Irwansyah, Edy dan Moniaga, Jurike. 2014. Pengantar Teknologi Informasi. Yogyakarta: Deepublish.

Labulan, PM dan Effendi, Fahrul. 2012. Pengembangan Smart Try Out System Berbasis Komputer pada Mata pelajaran Matematika di Sekolah Kejuruan. AKSIOMA.Vol.01.No.01.[Online].

Tersedia:http://jurnal.untad.ac.id/jurnal/index .php/AKSIOMA/article/view/1282.

Mardika. 2008. Pengembangan Multimedia Dalam Pembelajaran Kosakata Bahasa Inggris di $S D$. [Online]. Tersedia: http://mardikanyom.tripod.com/Multimedia.p df.

Mukhtar, Iskandar. 2012. Desain pembelajaran Berbasis TIK. Jakarta: Gaung Press GP Persada.

Nasution, S. 1982. Teknologi Pendidikan. Bandung: CV Jemmars.

Nursalam dan Efendi, Ferry. 2011. Pendidikan dalam keperawatan. Jakarta: Salemba Medika.

Sommerville, Ian. 2003. Software Engineering Rekayasa Perangkat Lunak . Jakarta: Erlangga.

Sugiyono. 2013.Metode Penelitian Kuantitatif Kualitatif dan R\&D. Bandung: Alfabeta. 
Sukmadinata dan Syaodih, Nana. 2006. Metode Penelitian pendidikan. Bandung: Remaja Rosdakarya.

Sunarti dan Rahmawati, Selly. 2013. Penilaian Dalam Kurikulum 2013. Yogyakarta: Penerbit Andi.

Supriyanto, Aji. 2005. Pengantar Teknologi Informasi. Jakarta: Salemba Infotek.

Suyanto dan Herman, Asep. 2007. Web Design Theory and Practices. Yogyakarta: Penerbit Andi.

Tulangow, Bobby Melky. 2011. Sistem Ujian Berbasis Web. TEKNOMATIKA STMIK PalComTech Palembang. Vol 1. No 1. [Online]. Tersedia:

http://news.palcomtech.com/wpcontent/uploads/2012/01/BOBBY TE01012011.pdf.

Wahana Komputer. 2010. Membangun Website Tanpa Modal. Semarang: Penerbit Andi. 